\title{
The Effect of Learning Intensity on Mathematics Learning Outcomes To Fourth Grade Students of Public Elementary School In Klirong Sub-District In Academic Year of 2019/2020
}

\author{
Tanti Oktaviani Kusuma, Ngatman, Joharman \\ Universitas Sebelas Maret \\ to.kusuma22@gmail.com
}

\section{Article History \\ accepted 01/06/2020}

approved 01/07/2020 published 01/08/2020

\begin{abstract}
The study aimed to determine positive effect of learning intensity on mathematics learning outcomes to fourth grade students and to determine the effective contribution of learning intensity on mathematics learning outcomes to fourth grade students of public elementary school in Klirong sub-district in academic year of 2019/2020. It was quantitative research with correlation method. Sampling method was probability sampling. Data analysis used SPSS application in analyzing data correlation. The results showed that the correlation coefficient between learning intensity and mathematics learning outcomes was 0.580 with Sig. $=0,000$ $<0.05$ and the adjusted $R$ squared value of learning intensity on student mathematics learning outcomes was $33.7 \%$. It concludes that there is a positive and significat effect between learning intensity and mathematics learning outcomes to fourth grade students of public elementary school in Klirong sub-district in academic year of 2019/2020.
\end{abstract}

Keywords: learning intensity, mathematics learning outcomes

\begin{abstract}
Abstrak
Penelitian ini bertujuan untuk mengetahui adanya pengaruh positif frekuensi belajar terhadap hasil belajar matematika siswa kelas IV dan untuk mengetahui besar sumbangan efektif frekuensi belajar terhadap hasil belajar matematika siswa kelas IV SD Negeri se-Kecamatan Klirong tahun ajaran 2019/2020. Penelitian ini merupakan penelitian kuantitatif dengan metode korelasi. Pengambilan sampel dilakukan dengan teknik probability sampling. Pada analisis data penelitian, peneliti menggunakan aplikasi SPSS dalam menganalisis korelasi data. Hasil penelitian menunjukkan bahwa nilai koefisien korelasi antara frekuensi belajar terhadap hasil belajar matematika sebesar 0,580 dengan nilai Sig. $=0,000<0,05$. Nilai sumbangan efektif variabel frekuensi belajar terhadap hasil belajar matematika siswa sebesar $33,7 \%$. Berdasarkan analisis dan pembahasan hasil penelitian dapat disimpulkan bahwa terdapat pengaruh positif dan signifikan antara frekuensi belajar dengan hasil belajar matematika siswa kelas IV SD Negeri se-Kecamatan Klirong tahun ajaran 2019/2020.
\end{abstract}

Kata Kunci: frekuensi belajar, hasil belajar matematika 


\section{PENDAHULUAN}

Khairiah (2018) menjelaskan bahwa peran pendidikan sangat penting dalam kehidupan manusia. Setiap individu berhak untuk mendapatkan pendidikan. Proses belajar penting dilakukan oleh setiap individu untuk menyesuaikan diri dengan lingkungan sekitarnya. Salah satu indikator siswa dapat dikatakan telah menguasai suatu bahan kajian atau ilmu yaitu dengan melihat hasil belajarnya.

Sudjana (2013) menyatakan hasil belajar adalah kemampuan-kemampuan yang dimiliki siswa setelah ia menerima pengalaman belajarnya. Syah (2013) menyatakan bahwa setiap siswa yang telah mengalami proses belajar akan terlihat perubahan dalam kebiasaan-kebiasaan yang dilakukannya. Perubahan kebiasaan ini akan menimbulkan suatu pola baru yang cenderung akan menetap dan berlangsung secara otomatis. Contohnya siswa yang memiliki kebiasaan belajar 2-3 jam setiap malamnya akan memiliki pola belajar yang berulang-ulang dan menetap pada setiap malamnya.

Khairiah (2018) menyatakan bahwa pendidikan dapat berlangsung dimana saja, baik di lingkungan keluarga, sekolah, atau masyarakat. Belajar adalah suatu aktivitas untuk memperoleh pengetahuan, meningkatkan keterampilan, memperbaiki perilaku, sikap, dan mengukuhkan kepribadian (Suyono dan Hariyanto, 2014). Aunurrahman (2013) menyatakan bahwa belajar adalah interaksi atau hubungan timbal balik antara individu dengan individu lainnya atau objek lain yang memungkinkan individu tersebut memperoleh pengalaman atau pengetahuan baru.

Giyarso (2010) menjelaskan bahwa dalam belajar dibutuhkan kekerapan dalam melakukannya. Tidak perlu waktu yang lama untuk belajar. Sebaiknya belajar dilakukan sesering mungkin dan berkualitas daripada belajar dalam waktu yang lama tetapi tidak berkualitas dan membuat seseorang kesulitan dalam belajar. Giyarso (2010) menambahkan bahwa ketika siswa sering melakukan kegiatan belajar maka prestasi belajar yang didapatkan siswa akan baik. De Gruyter (2012) menyatakan bahwa "Learning, memory, and perception are all affected by frequency of usage: The more times we experience something, the stronger our memory for it, and the more fluently it is accessed' yang berarti belajar, ingatan, dan persepsi semuanya dipengaruhi oleh penggunaan frekuensi. Semakin sering kita mengalami sesuatu, semakin kuat ingatan kita tentang pengalaman tersebut.

Menurut Suranto (2014), "frekuensi belajar adalah kekerapan seseorang atau siswa dalam melakukan kegiatan belajar, yaitu dalam proses perubahan tingkah laku individu kearah yang lebih berkualitas dan relatif menetap melalui interaksi dengan lingkungannya sebagai hasil dari latihan dan pengalaman". Menurut Astutik (2016), "frekuensi belajar merupakan intensitas atau banyaknya belajar yang dapat dikaitkan dengan kekerapan dan pengulangan". Syah (2015) menjelaskan hukum Jost dalam belajar materi selama 3 jam sehari selama 5 hari akan lebih efektif apabila dilakukan dibandingkan dengan alokasi waktu 5 jam sehari dalam waktu 3 hari.

Frekuensi belajar dipengaruhi oleh faktor internal dan faktor eksternal. Faktor internal terdiri dari motivasi siswa dalam belajar, kenyamanan dalam belajar, cara belajar, tempo dan irama belajar, hal-hal yang bersifat fisik (sakit, cacat tubuh, dan lain-lain), dan hal-hal yang bersifat kerohanian (intelegensi, bakat, minat, dan motivasi). Faktor eksternal berasal dari waktu belajar, fasilitas belajar (sumber belajar, media belajar, dan tempat belajar), faktor lingkungan keluarga (orang tua, suasana rumah, dan keadaan ekonomi keluarga), dan faktor lingkungan masyarakat (media massa, teman bergaul, lingkungan tetangga, aktivitas dalam sekolah dan masyarakat). 
Penelitian Rohmawati (2015) mengungkapkan bahwa sekitar 65\% siswa memiliki frekuensi belajar rendah. Pada umumnya siswa kurang sering belajar. Siswa tidak akan belajar apabila tidak ada ulangan atau pekerjaan rumah. Siswa biasanya belajar dalam intensitas waktu yang singkat. Banyak dijumpai pula bahwa dalam pembelajaran, siswa tidak mengetahui materi yang akan disampaikan oleh guru. Hal ini disebabkan bahwa siswa kurang dalam belajarnya atau bahkan tidak belajar di rumah.

Tujuan dari penelitian ini yaitu: (1) untuk mengetahui adanya pengaruh positif frekuensi belajar terhadap hasil belajar matematika siswa kelas IV SD Negeri seKecamatan Klirong tahun ajaran 2019/2020; (2) untuk mengetahui seberapa besar sumbangan efektif frekuensi belajar terhadap hasil belajar matematika siswa kelas IV SD Negeri se-Kecamatan Klirong tahun ajaran 2019/2020.

\section{METODE}

Desain penelitian yang digunakan yaitu penelitian kuantitatif dengan metode penelitian korelasi. Menurut Purwanto (2010), "penelitian korelasi adalah penelitian yang melibatkan hubungan satu atau lebih variabel lain". Populasi dalam penelitian ini adalah semua siswa kelas IV SDN se-Kecamatan Klirong sejumlah 841 siswa dengan sampel sebanyak 285 siswa di sebelas SDN di Kecamatan Klirong. Pengambilan sampel penelitian dilakukan dengan teknik probability sampling jenis cluster random sampling.

Teknik pengumpulan data pada penelitian ini yaitu angket dan tes. Angket digunakan untuk mengumpulkan data pada variabel frekuensi belajar, sedangkan tes digunakan untuk mengumpulkan data pada variabel hasil belajar matematika. Pada penelitian ini, untuk menghitung reliabilitas peneliti menggunakan rumus Cronbach's Alpha.

Peneliti menggunakan aplikasi SPSS versi 26 dalam menguji hipotesis. Uji prasyarat data penelitian ini yaitu uji normalitas dan uji linieritas data. Uji normalitas data digunakan untuk mengetahui apakah data yang dianalisis dengan statistik parametric berdistribusi normal. Uji normalitas menggunakan metode uji Kolmogorov Smirnov. Uji linieritas dilakukan sebagai salah satu syarat untuk melakukan analisis korelasi data.

Analisis korelasi yang digunakan yaitu analisis korelasi Pearson Product Moment. Setelah melakukan analisis korelasi selanjutnya menghitung besar sumbangan efektif (SE). Sumbangan efektif merupakan sumbangan suatu variabel prediktor terhadap variabel kriterium.

HASIL DAN PEMBAHASAN

Penelitian dilakukan dengan memberikan angket frekuensi belajar dan soal tes hasil belajar matematika di SD yang menjadi sampel penelitian. Uji prasyarat data pada penelitian ini telah terpenuhi yaitu data berdistribusi normal dan data berhubungan linier.

Tabel 1. Hasil Analisis Uji Normalitas Variabel Hasil Belajar Matematika Tests of Normality

\begin{tabular}{lccc}
\hline & \multicolumn{3}{c}{ Kolmogorov-Smirnov } \\
\cline { 2 - 4 } & Statistic & df & Sig. \\
\hline HASIL BELAJAR &, 051 & 285 &, 074 \\
\hline
\end{tabular}


Tabel 2. Hasil Analisis Uji Normalitas Variabel Frekuensi Belajar Tests of Normality

\begin{tabular}{lccc}
\hline & \multicolumn{3}{c}{ Kolmogorov-Smirnov ${ }^{\mathrm{a}}$} \\
\cline { 2 - 4 } & Statistic & df & Sig. \\
\hline FREKUENSI BELAJAR &, 027 & 285 &, $200^{*}$ \\
\hline
\end{tabular}

Data hasil belajar matematika berdistribusi normal ditunjukkan dengan nilai signifikasi sebesar 0,074 pada tabel 1 dan data frekuensi belajar berdistribusi normal dengan nilai signifikansi sebesar 0,200 pada tabel 2. Nilai signifikansi pada kedua variabel tersebut menunjukkan $>0,05$ sehingga data berdistribusi normal.

Tabel 3. Hasil Uji Linieritas Data Hasil Belajar Matematika dan Frekuensi Belajar

\begin{tabular}{llll}
\hline & & $\mathrm{F}$ & Sig. \\
\hline HASIL & (Combined) & 3,432 &, 410 \\
BELAJAR $^{*}$ & Linearity & 327,163 &, 035 \\
FREKUENSI & Deviation from & 2,283 &, 491 \\
BELAJAR & Linearity & & \\
\hline
\end{tabular}

Data hasil belajar matematika dan data frekuensi belajar memiliki hubungan yang linier, hal tersebut ditunjukkan dari nilai Sig. Deviation from Linearity sebesar 0,491 pada tabel 3. Nilai Sig. Deviation from Linearity $>0,05$ sehingga data hasil belajar matematika dan data frekuensi belajar memiliki hubungan yang linier.

Data frekuensi belajar dan hasil belajar matematika yang telah lolos uji prasyarat selanjutnya dilakukan analisis data uji hipotesis.

Tabel 4. Hasil Analisis Korelasi Frekuensi Belajar dan Hasil Belajar Matematika

\section{Correlations}

\begin{tabular}{llrr}
\hline & & $\begin{array}{c}\text { HASIL } \\
\text { BELAJAR }\end{array}$ & $\begin{array}{r}\text { FREKUENSI } \\
\text { BELAJAR }\end{array}$ \\
\hline HASIL & Pearson Correlation & 1 &, $580^{\star *}$ \\
BELAJAR & Sig. (1-tailed) & &, 000 \\
& $N$ & 285 & 285 \\
FREKUENSI & Pearson Correlation &, $580^{* *}$ & 1 \\
BELAJAR & Sig. (1-tailed) &, 000 & \\
& $\mathrm{~N}$ & 285 & 285 \\
\hline
\end{tabular}

${ }^{* *}$. Correlation is significant at the 0.05 level (1-tailed).

Berdasarkan analisis yang telah dilakukan, diketahui nilai Sig. (1-tailed) yaitu 0,000 pada tabel 4. Hal ini berarti nilai signifikansi $<\alpha(0,000<0,05)$, artinya hipotesis penelitian ini dapat diterima atau terdapat hubungan positif antara frekuensi belajar dan hasil belajar matematika siswa kelas IV SDN se-Kecamatan Klirong tahun ajaran 2019/2020. Hasil penelitian ini sesuai dengan penelitian yang dilakukan oleh Iswahyuni 
(2017) yang menyatakan bahwa frekuensi belajar berpengaruh positif dan signifikan terhadap hasil belajar. Hal yang sama juga diungkapkan oleh Rohmawati (2013) yang mengungkapkan bahwa frekuensi belajar berpengaruh positif dan signifikan terhadap prestasi belajar. Oleh karena itu, dapat dikatakan bahwa semakin tinggi frekuensi belajar siswa, maka akan semakin tinggi pula hasil belajar matematika siswa. Begitu pun sebaliknya, semakin rendah frekuensi belajar siswa, maka akan semakin rendah pula hasil belajar matematika siswa.

Hasil analisis koefisien korelasi antara variabel frekuensi belajar dan hasil belajar matematika yaitu 0,580. Berdasarkan pendapat Sugiyono (2013) mengenai pedoman interpretasi koefisien korelasi menyatakan bahwa koefisien korelasi pada penelitian ini 0,580 berada pada tingkat hubungan sedang. Tingkat hubungan yang sedang pada penelitian ini sejalan dengan hasil penelitian Astutik (2016) yang menyatakan bahwa terdapat hubungan positif dan signifikan antara frekuensi belajar dengan hasil belajar matematika siswa dengan koefisien korelasinya 0,451 yang menunjukkan tingkat hubungan yang sedang. Tingkat hubungan yang sedang ini dapat disebabkan karena adanya faktor-faktor lain diluar frekuensi belajar yang memiliki hubungan yang lebih baik terhadap hasil belajar matematika seperti faktor intelegensi, minat belajar, dan motivasi belajar.

Hasil perhitungan sumbangan efektif pada variabel frekuensi belajar dan hasil belajar matematika didapatkan hasil sebesar 33,7\%\%, artinya frekuensi belajar berperan dalam meningkatkan hasil belajar matematika sebesar $33,7 \%$ dan sisanya sebesar $66,3 \%$ dipengaruhi oleh faktor lain.

\section{SIMPULAN}

Berdasarkan hasil penelitian yang telah dilakukan dapat disimpulkan bahwa: (1) frekuensi belajar memiliki pengaruh positif terhadap hasil belajar matematika siswa kelas IV SD Negeri se-Kecamatan Klirong tahun ajaran 2019/2020 dengan nilai pearson correlation 0,580 , (2) sumbangan variabel frekuensi belajar terhadap hasil belajar matematika siswa kelas IV SD Negeri se-Kecamatan Klirong tahun ajaran 2019/2020 adalah 33,7\%.

Berdasarkan simpulan yang telah disebutkan, peneliti memberikan beberapa saran sebagai berikut: (1) Guru hendaknya memerhatikan frekuensi belajar siswa pada setiap mata pelajaran, baik di sekolah maupun di luar sekolah, sehingga dapat meningkatkan hasil belajar siswa, (2) Pihak sekolah diharapkan bersedia memberikan dukungan dan pengarahan kepada guru untuk meningkatkan kualitas pembelajaran di kelas sehingga waktu belajar di kelas dapat digunakan dengan baik, dan (3) peneliti selanjutnya yang ingin mengkaji tentang frekuensi belajar dan hasil belajar matematika siswa diharapkan mencari sumber referensi lainnya agar penelitian selanjutnya akan jauh lebih baik.

\section{DAFTAR PUSTAKA}

Astutik, N.D. (2016). Pengaruh Frekuensi dan Fasilitas Belajar terhadap Hasil Belajar Siswa Kelas Atas di SDN Kedungwaduk 1 Sragen Tahun Pelajaran 2015/2016. Skripsi Dipublikasikan. Surakarta: FKIP Universitas Muhammadiyah Surakarta.

Aunurrahman. (2013). Belajar dan Pembelajaran. Bandung: Alfabeta.

De Gruyter, M. (2012). Frequency Effects in Language Learning and Processing. Jerman: Hubert \& Co. 
Giyarso, A.D. (2010). Hubungan Frekuensi Belajar dan Kepercayaan Diri dengan Prestasi Belajar KKPI Siswa Kelas X SMK Kasatrian Solo Sukoharjo Tahun Pelajaran 2010/2011. Tesis. Surakarta: Program Pasca Sarjana Universitas Sebelas Maret.

Iswahyuni, R. (2017). Pengaruh Pola Belajar dan Frekuensi Belajar terhadap Hasil Belajar Siswa Kelas VII SMP Negeri 3 Janapria Mata Pelajaran IPA Biologi Sub Pembahasan Sistem Pernapasan. Skripsi Dipublikasikan. Mataran: Universitas Islam Negeri.

Khairiah. (2018). Kesempatan mendapatkan Pendidikan dalam Kajian Tingkat Pendidikan dan Pendapatan Keluarga. Yogyakarta: Pustaka Pelajar.

Purwanto. (2010). Metodologi Penelitian Kuantitatif untuk Psikologi dan Pendidikan. Yogyakarta: Pustaka Pelajar.

Rohmawati, D.N. (2015). Pengaruh Frekuensi Belajar Dan Kemandirian Belajar Terhadap Prestasi Belajar Kelas V SD Negeri 01 Potronayan Tahun Pelajaran 2014/2015. Skripsi Dipublikasikan. Surakarta: FKIP Universitas Muhammadiyah Surakarta.

Rohmawati, F. N. (2013). Pengaruh Pola Belajar dan Frekuensi Belajar terhadap Prestasi Belajar Siswa Kelas XI IPA SMA Negeri Jumapolo pada Mata Pelajaran Biologi. Naskah Publikasi. Surakarta: Universitas Muhammadiyah Surakarta.

Sudjana, N. (2013). Penilaian Hasil Proses Belajar Mengajar. Bandung: PT Remaja Rosdakarya.

Sugiyono. (2013). Metode Penelitian Pendidikan (Pendekatan Kuantitatif, Kualitatif, dan $R \& D)$. Bandung: Alfabeta.

Suranto. (2014). Pengaruh Frekuensi Belajar dan Prestasi Belajar Dasar Akuntansi Keuangan terhadap Prestasi Belajar Praktek Akuntansi I Mahasiswa Pendidikan Ekonomi Akuntansi FKIP Universitas Muhammadiyah Surakarta Tahun Ajaran 2014/2015. Prosiding dari Seminar Nasional Pendidikan Akuntansi dan Keuangan. Surakarta: UMS.

Suyono dan Hariyanto. (2014). Belajar dan Pembelajaran Teori dan Konsep Dasar. Bandung: PT Remaja Rosdakarya.

Syah, M. (2013). Psikologi Pendidikan. Bandung: PT. Remaja Rosdakarya.

Syah, M. (2015). Psikologi Belajar. Jakarta: PT Rajagrafindo Persada. 